\title{
Neuronal and Non-Neuronal Aromatase in Primary Cultures of Developing Zebra Finch Telencephalon
}

\author{
Barney A. Schlinger, ${ }^{1}$ Shashi Amur-Umarjee, ${ }^{2}$ Peter Shen, ${ }^{3}$ Anthony T. Campagnoni, ${ }^{2}$ and Arthur P. Arnold ${ }^{\dagger}$ \\ Departments of ${ }^{1}$ Psychology, ${ }^{2}$ Psychiatry, and ${ }^{3}$ Anatomy and Cell Biology, Mental Retardation Research Center, and \\ Laboratory of Neuroendocrinology of the Brain Research Institute, University of California at Los Angeles, Los Angeles, \\ California 90024
}

Estrogenic metabolites of circulating androgens have important effects on the organization and activation of neural circuits controlling reproductive behavior and physiology in males of many vertebrate species. Previous studies indicate that aromatase, the enzyme that converts androgens to estrogens, is expressed most abundantly in neurons in limbic brain regions. Songbirds are unique in that aromatase is expressed at unusually high levels throughout the telencephalon of both males and females. We assume that estrogens formed in the telencephalon itself masculinize neural circuits controlling song, since the brain is a major source of circulating estrogens in adult males. However, the cellular localization of telencephalic aromatase in songbirds remains unknown. We have established primary cultures from telencephalons of developing zebra finches and found aromatase activity (conversion of ${ }^{3} \mathrm{H}$-androstenedione or ${ }^{3} \mathrm{H}$-testosterone to ${ }^{3} \mathrm{H}$-estrone plus ${ }^{3} \mathrm{H}$-estradiol) at some of the highest levels reported for brain tissue of any species. Both neurons and glia were identified in these cultures based on cell morphology and labeling by specific immunohistochemical markers. However, when culture conditions were manipulated to reduce the incidence of either neurons or glia by varying the age of cultures or their plating density, treating with the neurotoxin kainic acid, physically shaking off loosely attached neurons, or preparing cultures in media that encouraged enrichment of neurons, high levels of aromatase persisted. Furthermore, Northern blot analysis of total RNA extracted from enriched neuronal or glial cultures indicated the presence of aromatase mRNA in both cell preparations. In situ hybridization with a zebra finch aromatase cDNA probe conjugated to digoxigenin showed the cultures contained darkly labeled neurons and lightly labeled non-neuronal cells, presumably astrocytes. We conclude that aromatase is expressed in both neuronal and non-neuronal cells in these cultures, suggesting that both cell types may also express

\footnotetext{
Received Sept. 29, 1993; revised May 5, 1994; accepted June 2, 1994.

Our thanks to Dr. Steven Goldman for advice on use of antibodies; to Dr. Juli Wade for assisting with experiments on aromatase inhibitors; to Vance Handley, Ana Vanson, Tom Phan, and Lori Miyasato for excellent technical help; and to Dr. Jean De Vellis, Dr. John Edmond, and Ruth Cole for sharing their unpublished method for growing neurons in culture. Fadrozole $\mathrm{HCl}$ was a gift of Ciba-Geigy Corp. This work was supported by BNS-9020953 and IBN 9120776 from the National Science Foundation, DC00217 and NS23022 from the National Institutes of Health, and RG2233-1-A from the National Multiple Sclerosis Society.

Correspondence should be addressed to Dr. Barney Schlinger, Department of Physiological Science, UCLA, 405 Hilgard Avenue, Los Angeles, CA 90024.

Copyright (C) 1994 Society for Neuroscience 0270-6474/94/147541-12\$05.00/0
}

the enzyme in vivo. The presence of aromatase outside of neurons suggests that glia may be targets of estrogen action or that glia may supply some estrogen to the estrogen-sensitive neural circuits in this species.

[Key words: estrogen, androgen, sexual differentiation, masculinization, song system]

Estrogens have diverse actions on brain that are essential for the organization and the activation of neural circuits controlling reproductive behavior and physiology (McEwcn ct al., 1982; Pfaff, 1983; Arnold and Gorski, 1984; Blaustein and Olster, 1989; Schlinger and Callard, 1991). In females, the brain is generally considered a target of estrogens secreted into the circulation at high levels by the ovary (Pfaff, 1983; Siiteri and Febres, 1989). In contrast, estrogens generally circulate at low levels in males. However, aromatase cytochrome P450, the enzyme that catalyzes the conversion of androgen to estrogen, is present in the male brain (Naftolin et al., 1975; McEwen et al., 1982; Callard, 1984; Maclusky et al., 1987; Schlinger and Callard, 1991). Consequently, circulating androgens in males can be converted to estrogens near estrogen targets in brain to influence neural development and function.

Songbirds have proven to be especially useful models for studying estrogen effects on neural development. For example, male zebra finches sing courtship and territorial songs that are not sung by females, and the brain regions controlling song are correspondingly much larger in males than in females (Nottebohm and Arnold, 1976). It is assumed that estrogen is the principal masculinizing hormone since hatchling female zebra finches treated with estradiol develop more masculine neural song systems than untreated females (Gurney and Konishi, 1980). Interestingly, unlike males of many other vertebrates, estradiol is present at high levels in blood of hatchling and adult male zebra finches (Hutchison et al., 1984; Adkins-Regan et al., 1990; Schlinger and Arnold, 1991, 1992a). In addition, aromatase is present at high levels in the zebra finch brain, especially in the telencephalon near the song system (Vockel et al., 1990; Schlinger and Arnold, 1991, 1992a). However, since aromatase cannot be detected at significant levels in zebra finch testes or adrenals (Schlinger and Arnold, 1991, 1992a,b), and estrogens can be synthesized and released into blood if androgenic precursors are available to the brain of adult males (Schlinger and Arnold, $1992 \mathrm{~b}, 1993$ ), the brain appears to be the source of the estrogen found circulating in the blood of males. This result implies that the brain is the synthetic source of the estrogen that triggers the masculine development of the song system. 
We assume that the capacity of brain to secrete estrogen into the circulation is a unique consequence of the heightened expression of aromatase in the zebra finch telencephalon. Ordinarily, the synthesis of estrogens in the male brain is thought to occur in a relatively small number of neurons that are near or are themselves estrogen targets, primarily in limbic brain structures. Measures of aromatase in cultures from developing rat hypothalamus (Canick et al., 1986), in synaptosomal preparations of goldfish brain (Mak et al., 1985), and in adult quail hypothalamus-preoptic area (Schlinger and Callard, 1989) have suggested that aromatase is present in neurons. This idea has been confirmed by immunohistochemistry on brain sections using antibodies prepared against aromatase or a fragment of the aromatase protein (Shinoda et al., 1989a,b; Balthazart et al., 1990, 1991a; Sanghera et al., 1991). Paradoxically, immunostained neuronal somata are not always seen in brain regions that demonstrate aromatase activity (Shinoda et al., 1989a,b; Balthazart et al., 1990, 1991a; Sanghera et al., 1991). This disparity is most conspicuous in the zebra finch, in which available antibodies recognize aromatase in hypothalamic regions but not the telencephalon, even though aromatase activity is higher in telencephalon (Balthazart et al., 1990).

For further exploration of brain steroid synthesis and steroid action in the zebra finch brain, we have prepared dissociated mixed-cell cultures of telencephalons of zebra finches in the first $5 \mathrm{~d}$ after hatching. These cultures provide a useful system to determine the types of cells that express aromatase, and to study the regulation of this enzyme. In the present study, we report that cultures of the zebra finch telencephalon express extremely high levels of aromatase activity. Conditions that reduce the proportion of neurons in these cultures have little effect on the activity of aromatase, suggesting that aromatase is present in non-neural cells. To test this idea further, we prepared purified glial cultures as well as cultures highly enriched with neurons. Both neuronal and glial cultures express aromatase activity. Moreover, an aromatase cDNA probe prepared from a zebra finch ovarian library hybridizes to Northern blots containing RNA from either glial or neuronal cultures. In addition, we used this probe labeled with digoxigenin in in situ hybridization analysis of cell cultures. Neurons stained darkly and non-neural cells, presumed to be astrocytes, stained lightly, indicating that both cell types contain aromatase mRNA. These results suggest that aromatase is present in neural and non-neuronal cells in the zebra finch telencephalon.

Portions of this study have appeared in abstract form (Arnold et al., 1992).

\section{Materials and Methods}

Preparation of primary cultures. Male and female zebra finch chicks, 1$5 \mathrm{~d}$ after hatching, were decapitated, and the entire brain or telencephalon was dissected from the skull. To dissect the telencephalon, a pair of forceps was inserted under aseptic conditions horizontally between the telencephalic lobes and the optic lobes at the caudal pole of the brain, and passed rostrally so that they were at the base of the brain at levels rostral to the optic commissure. In this manner the telencephalon was pinched off. Primary cultures of zebra finch brains were prepared essentially by the methods described earlier (Amur-Umarjee et al., 1990a). Briefly, cells from several male and female brains were dissociated by gently teasing the tissue through a nylon mesh $(210 \mu \mathrm{m})$ into a petri dish containing medium. The cells were then filtered through two stainless steel mesh filters ( $230 \mu \mathrm{m}$ then $140 \mu \mathrm{m}$ mesh, Bellco), centrifuged for $10 \mathrm{~min}$ at $1100 \mathrm{rpm}$, resuspended in medium, and plated into plastic culture dishes precoated with polylysine or fibronectin. Cultures were incubated at $37^{\circ} \mathrm{C}, 5 \% \mathrm{CO}_{2}$ in Dulbecco's Modified Eagle's Medium
(DMEM)/Ham's F12 (1:1; Irvine Scientific, Santa Ana, CA), supplemented with fetal calf serum (10\%), HEPES buffer (3.38 gm/liter), $\mathrm{NaHCO}_{3}(2.16 \mathrm{gm} /$ liter $)$, gentamicin $(0.09 \mathrm{gm} /$ liter $)$, and D-glucose $(3.6$ $\mathrm{gm} /$ liter). Cells were plated at one of three densities: 20,10 , or 5 paired telencephalons per $100 \mathrm{ml}$. After plating, cells were left undisturbed for $3 \mathrm{~d}$, after which the medium was replaced every 2 or $3 \mathrm{~d}$.

Glia-enriched cultures were prepared by shaking the primary cultures after $14 \mathrm{~d}$ in vitro (DIV) at $280 \mathrm{rpm}$ for $18-20 \mathrm{hr}$ as described previously (Amur-Umarjee et al., 1993). The supernatant containing unattached cells and debris was discarded. The remaining cells were harvested for RNA isolation. For in situ hybridization of glia-enriched cultures, primary cultures were shaken at $13 \mathrm{DIV}$, the adhering glia were removed using $0.01 \mathrm{M}$ EDTA, centrifuged, resuspended in media, and plated at a density of 50,000 cells per chamber in eight-chamber slides. The cells were processed for in situ hybridization after $1 \mathrm{~d}$. Primary neuronenriched cultures were prepared in the absence of cytosine arabinoside using a modification of the procedure described by Syapin et al. (1985; De Vellis, Edmond, and Cole, unpublished observations) in which survival of oligodendrocytes and astrocytes is poor. Cells were plated in a chemically defined medium containing bovine insulin ( $5 \mathrm{mg} /$ liter), human transferrin $(5 \mathrm{mg} /$ liter), Na selenite $(5 \mathrm{mg} /$ liter), BSA (fraction $\mathrm{V}$; $500 \mu \mathrm{g} / \mathrm{liter})$, oleic acid $(4.8 \mathrm{mg} / \mathrm{liter})$, and $2 \%$ fetal calf serum. After 4 d, $50 \%$ of the media was removed and replaced with serum-free media. Neuron-enriched cultures were used experimentally after 7 DIV.

Immunohistochemistry. Some cells were cultured on glass coverslips for 1-5 weeks, and then washed with phosphate-buffered saline containing $1 \% \mathrm{CaCl}_{2}, 1 \% \mathrm{MgCl}_{2}$, and $0.2 \%$ sodium azide [phosphate-buffered saline (PBS), $\mathrm{pH} 7.2$ ], fixed for 15 min with $4 \%$ paraformaldehyde in PBS, washed in $0.1 \%$ Triton X-100 in PBS, and then incubated in normal goat serum [NGS; $5 \%$ in Tris-buffered saline (TBS)] as a blocking agent. Cells were incubated with mild agitation in various primary antibodies (see below) in 5\% NGS for $1 \mathrm{hr}$, and then washed with TBS and incubated for $1 \mathrm{hr}$ in secondary antibodies similarly diluted in 5\% NGS. Secondary antibodies (Boehringer Mannheim, Indianapolis, IN, or Vector Laboratories, Burlingame, CA) were conjugated with fluorescein or rhodamine for visualization with fluorescence light microscopy, or with biotin. After incubation with biotinylated secondary antibodies, a biotin-avidin-peroxidase reaction was run using the Elite $A B C$ kit from Vector Laboratories. In addition to immunohistochemical labels, cell nuclei often were also stained with Hoechst dye that was added to the secondary antibody solution. Coverslips were mounted unto microscope slides and viewed under a fluorescence or bright-field compound microscope. The specificity of the immunohistochemical method was verified by incubating control cultures without primary or secondary antibodies, or with preimmune rabbit or mouse serum substituted for primary antisera.

The following antibodies were used routinely to characterize cultures: monoclonal anti-microtubule-associated protein 2 (MAP2), clone HM-2 (Sigma, St. Louis, MO); monoclonal anti-microtubule-associated protein 5 (MAP5), clone AA6 (Sigma); monoclonal anti-neurofilament 200, clone N52 (Sigma); polyclonal anti-vimentin (Chemicon, Temecula, CA); polyclonal anti-rat neuron-specific enolase (NSE) (Polysciences, Inc., Warrington, PA); monoclonal anti-galactocerebroside, gift of Dr. Joyce Benjamins (Ranscht et al., 1982). In addition, we used commercially available antibodies against a variety of other antigens that were less useful in characterizing the cells, including antibodies against S-100 protein, A2B5, synaptophysin, parvalbumin, and glial fibrillary acidic protein (GFAP).

Aromatase assays. Aromatase was analyzed in primary cultures by measuring conversion of $1,2,6,7-{ }^{3} \mathrm{H}$-androstenedione ( $\mathrm{AE}$; specific activity, 86.4 or $88.0 \mathrm{Ci} / \mathrm{mmol}$ ) or $1,2,6,7-{ }^{3} \mathrm{H}$-testosterone ( $\mathrm{T}$; specific activity, 87.1 or $91.3 \mathrm{Ci} / \mathrm{mmol})$ to ${ }^{3} \mathrm{H}$-estrogens [estrone $\left(E_{1}\right)$ and estradiol $\left.\left(\mathrm{E}_{2}\right)\right]$. Most of these procedures have been validated and described previously for homogenates or subcellular fractions of brain and peripheral tissues of quail and zebra finches (Schlinger and Callard, 1987, 1989; Schlinger and Arnold, 1991, 1992a). In brief, ${ }^{3} \mathrm{H}$-androgen, dissolved in a few microliters of ethanol, was added to culture media. Reactions were carried out at $37^{\circ} \mathrm{C}$ at various incubation times and substrate concentrations. Control cultures contained substrate but no tissue. Reactions were terminated by removing media from culture wells or flasks to test tubes placed on dry ice. Samples were then stored frozen until analyzed. For determination of procedural losses, some tubes with medium but no cells were processed in parallel after receiving approximately $100,000 \mathrm{cpm}$ of $6,7-{ }^{3} \mathrm{H}-\mathrm{E}_{1}$ (specific activity, $60 \mathrm{Ci} / \mathrm{mmol}$ ). Samples were extracted with diethyl ether $(3 \times 2 \mathrm{ml})$ and estrogenic products 
A

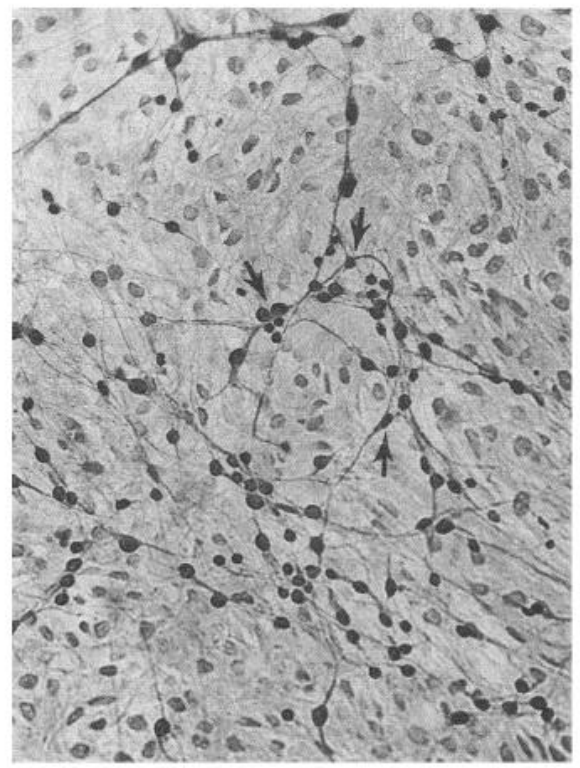

B

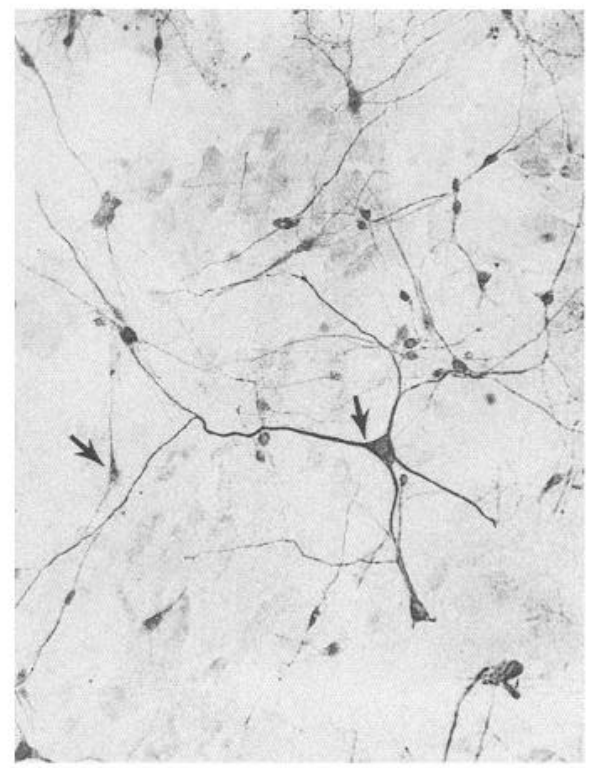

C

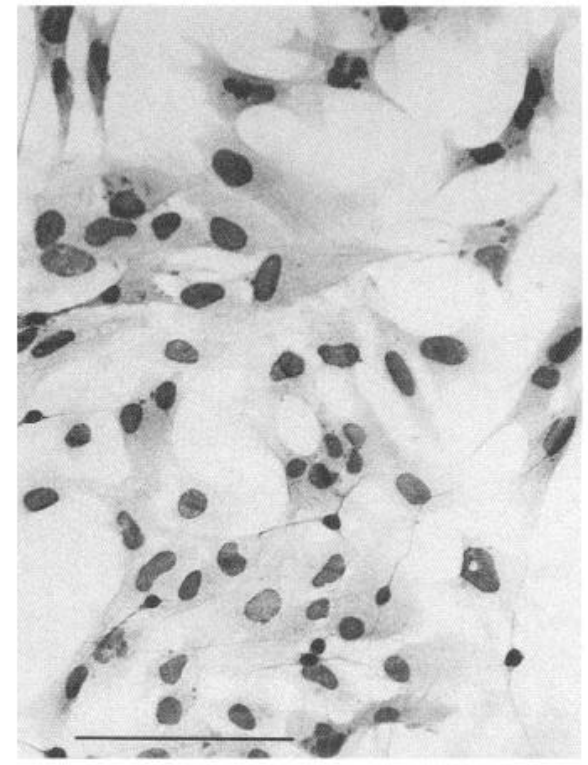

Figure 1. Photomicrographs of mixed neuronal-glial cultures after immunohistochemical labeling at 1 week in vitro. Left, Antibody against vimentin labels the nuclei of cells in the glial mat, as well as neuronal cell bodies and neurites (arrows). The darkly labeled neurons can be distinguished on the basis of cell morphology. Middle, The antibody against MAP2 labels exclusively neuronal cell bodies and neurites (arrows). Right, Cells on the edge of the glial mat, labeled with anti-vimentin, showing the irregular shape of some individual cells, which are presumed to be astrocytes. Scale bar, $100 \mu \mathrm{m}$.

were purified by double phenolic partition, using equal volumes of $\mathrm{CCl}_{4}$ and $0.1 N \mathrm{NaOH}$ followed by ethyl acetate extraction $(3 \times 5 \mathrm{vol})$. The ethyl acetate residues (to which radioinert $E_{1}$ and $E_{2}$ were added as carriers) or the $\mathrm{CCl}_{4}$ residues (to which radioinert $\mathrm{AE}$ and/or $\mathrm{T}$ were added as carriers) were then chromatographed twice on thin-layer silica gel (TLC) plates in ether/hexane (3:1) for $E_{1}, E_{2}$, and AE or chloroform/ ethyl acetate $(4: 1)$ for $T$. Androgens and estrogens were chromatographed separately. $E_{1}$ and $E_{2}$ carriers were visualized by exposure to iodine vapors; $\mathrm{AE}$ and $\mathrm{T}$ were carriers under ultraviolet irradiation. Silica gel from each product region was eluted in $15 \%$ aqueous methanol. Aliquots of product were then added to scintillation vials containing 4 $\mathrm{ml}$ of Biofluor (New England Nuclear) for estimation of radioactivity. In some experiments, additional areas of TLC plates containing phenolic residues were also scraped and radioactivity of unknown identity was quantified. Procedural losses were adjusted accordingly. Results were expressed as picomoles of product per time of incubation per milligram of protein. Proteins were measured by the method of Bradford (1976) using bovine serum albumin (BSA) as standard. For measurement of protein, cells were scraped off larger plates into $\mathrm{KPO}_{4}$ buffer $(3 \times)$ but were removed from smaller plates by treatment with trypsin/EDTA $(2 \times)$. BSA standards were diluted appropriately in $\mathrm{KPO}_{4}$ or trypsin/ EDTA.

Zebra finch aromatase cDNA probe. An aromatase cDNA probe (ZF1A) was isolated from a zebra finch ovarian cDNA library (Shen et al., 1994). This probe was sequenced in its entirety and found to be $87 \%$ homologous to chicken aromatase and was $3.2 \mathrm{~kb}$ in length. The entire probe was used for in situ hybridization and Northern blot experiments described below.

Northern blots and RNA isolation. Cells were harvested and total RNA was extracted from cell pellets by the method of Chomczynski and Sacchi (1987). Northern blots were prepared by the methods detailed by Kitamura et al. (1990). Total RNA concentrations were estimated spectrophotometrically by absorbance measurements at $260 \mathrm{~nm}$. Equivalence of loading of total RNA samples in individual lanes was determined by ethidium bromide staining of the rRNA bands on the gels.

In situ hybridization histochemistry. Primary-mixed cultures (7 DIV) or glia-enriched cultures (14 DIV) grown in eight-chamber slides were washed in PBS, fixed in freshly prepared $4 \%$ paraformaldehyde for 1 $\mathrm{hr}$, and stored in PBS at $4^{\circ} \mathrm{C}$ until use. The cDNA insert was labeled with digoxigenin conjugated to dUTP using a Genius random priming kit (Boehringer-Mannheim, Mannheim, Germany). In situ hybridization histochemistry was then performed according to procedures described previously (Amur-Umarjee et al., 1990b). To control for nonspecific hybridization, the cDNA probe was deleted from alternate chambers.

\section{Results}

\section{Identification of cell types}

The cultures were composed of mixed populations of neurons and glia. The cultures consisted of large flat cells with irregularly shaped somata that formed a "bed layer" upon which neurons grew (Fig. 1). The dominant cell type in the bottom layer attached readily to the substrate and grew steadily until a confluent mat of cells formed over a period of several weeks in vitro. Based on their morphology and their ability to divide readily in vitro, these cells were presumed to be glia, probably astrocytes (Fig. 1).

Neurons grew in significant numbers on the glial mat, often in large clumps, and with complex fasciculation of their neurites. They elaborated long processes that were clearly labeled by antibodies against MAP2 (Fig. 1). Neurons were labeled specifically also with antibodies against MAP5 (see Fig. 5), neurofilament, and neuron-specific enolase. Antibodies against MAP5 and MAP2 appeared to label all neurons, whereas neuron-specific enolase and neurofilament expression was less consistent. Labeling with the anti-neurofilament antibody was particularly intense along neurites of selected cells, whereas the antibodies against MAP5, MAP2, and neuron-specific enolase often recognized both somata and neurites. This pattern of labeling, along with the morphological observations, clearly establishes the presence of neurons in these cultures. However, we were unable to confirm the identity of the cells in the glial mat as astrocytes based on immunohistochemical labeling, since none of the an- 


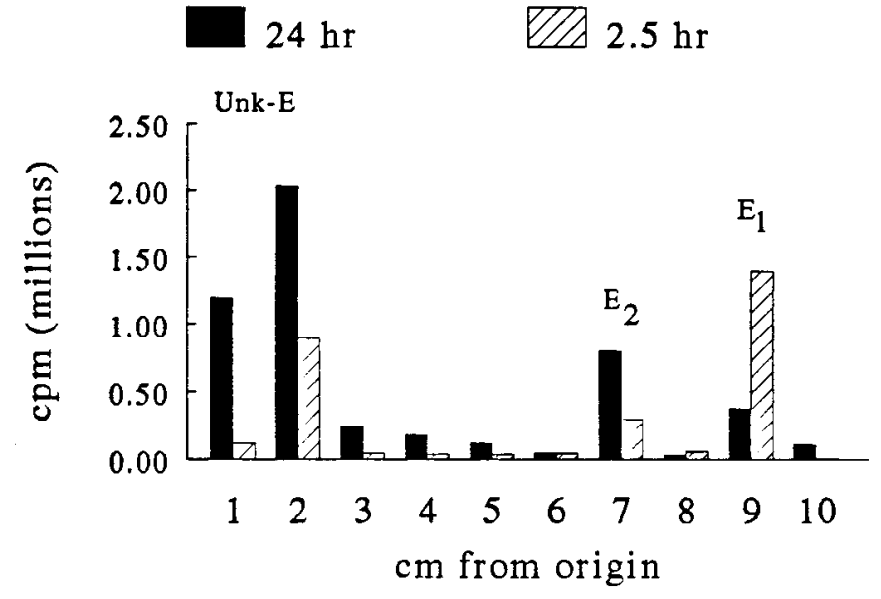

Figure 2. Radioactivity eluted from $1 \mathrm{~cm}$ scrapings of silica from thinlayer chromatography plates (run twice in ether/hexane, 3:1). Radioactivity was presumed to be estrogenic since it was retained in the phenolic fraction after double phenolic partition. The origin of the TLC plates was at $0 \mathrm{~cm} . E_{1}$ and $E_{2}$ were visualized by iodine vapors, and their identity was confirmed by triple recrystallization: for $E_{1}, 1448$ / $1468 \mathrm{DPM}_{\text {crystals }} / \mathrm{DPM}_{\text {mother liquor }}, 79 \%$ of initial radioactivity recovered; for $\mathrm{E}_{2}, 2103 / 2265 \mathrm{DPM}_{\text {crystas }} / \mathrm{DPM}_{\text {mother liquor }}, 93 \%$ of initial radioactivity recovered. The identity of the radioactive products present within $2 \mathrm{~cm}$ of the origin is unknown (Unk).

tibodies available to us labeled these cells specifically. For example, four different antibodies directed against mammalian or avian GFAP did not selectively recognize antigens in the putative glial mat, and in fact often resulted in more intense labeling of neurons than glia.

An antibody against galactocerebroside recognized a few cells with the classic morphology of oligodendrocytes, that is, small, round cell bodies with a large nuclear to cytoplasmic ratio from which emanated fine, reticulated branches. These oligodendrocytes were not typically observed in cultures after 7 DIV. The vast majority of data reported here were collected from cultures that appeared to lack oligodendrocytes.

The antibody against vimentin resulted in clear labeling of neuronal somata and neurites, and the nuclei of non-neurons (Fig. 1). The consistent labeling of neurons was established unequivocally in experiments in which cells were double labeled with anti-vimentin and anti-MAP2. This pattern of labeling differs from that observed using an antibody directed against canary vimentin, which did not label canary neurons in tissue sections (Alvarez-Buylla et al., 1987). However, vimentin can be expressed by early differentiating mammalian neurons in vitro (Bignami et al., 1982; Cochard and Paulin, 1984; Shea et al., 1993). Thus, the neuronal labeling we observed with an antibody raised against mammalian vimentin can be explained in a variety of ways. The canary and zebra finch neurons observed in the two studies could have differed in their developmental stage and/or expression of vimetin, or the antibody that we used may have recognized antigens other than vimentin. Whatever the reason, this antibody was useful because its labeling of neurons in fluorescence microscopy was more intense than that with the neuron-specific antibodies such as anti-MAP5 and anti-MAP2. Careful comparison of duplicate sister culture wells, labeled with these neuron-specific antibodies and with anti-vimentin under a variety of culture conditions (e.g., different plating densities, different ages of cultures, with or without ncurotoxin), lcft no doubt that neurons labeled with anti-vi-

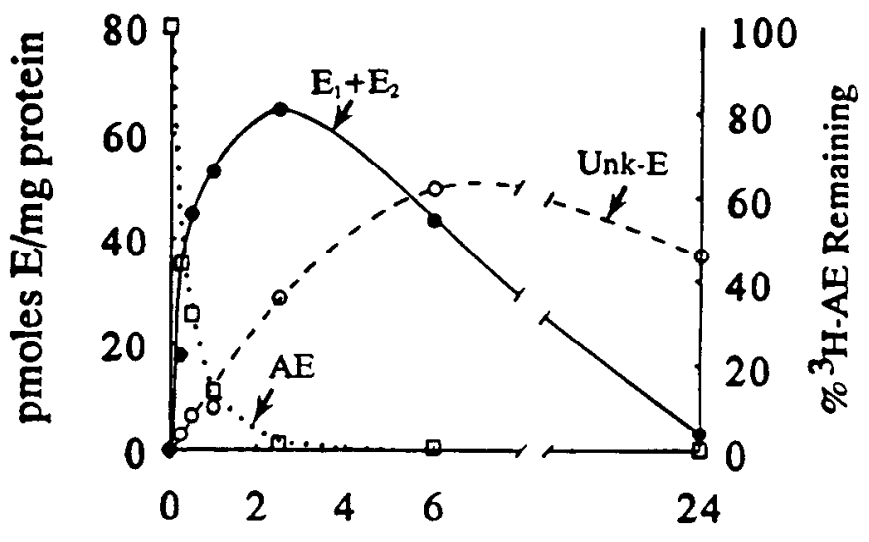

Incubation (hrs)

Figure 3. Time course of androstenedione $(A E)$ metabolism and its conversion to estrogen in developing zebra finch telencephalic cultures. Duplicate wells were incubated with $65 \mathrm{pmol} / \mathrm{ml}{ }^{3} \mathrm{H}-\mathrm{AE}$ for the indicated times. The percentage of initial ${ }^{3} \mathrm{H}-\mathrm{AE}$ remaining (dotted line) is indicated on the right abscissa. Aromatase activity (per mg protein) $\left(E_{i}\right.$ $\pm E_{2}$, solid line) and accumulation of unknown "phenolic" ${ }^{3} \mathrm{H}$ (dashed line; see Fig. 1) are indicated on the left abscissa.

mentin could be distinguished from non-neurons based on their morphology (small cell bodies and neuritic branches vs large nuclei of glia). Therefore, the antibody against vimentin was sometimes used as a label for quantitative measurements of the relative proportion of neurons and non-neurons under various culture conditions. In experiments on the effect of kainic acid, Hoechst dye was used to label all cell nuclei to allow counts of the total number of cells, and labeling with anti-vimentin was used to count the number of neurons.

Visual inspection of mixed cultures indicated that the proportion of neurons was higher when cells were plated at high density than at low density. Moreover, the percentage of neurons declined with the age of the cultures. These variations in the percentage of neurons were confirmed using counts of the proportions of neurons and glia (see below), and exploited to determine which cell types were responsible for the high levels of aromatase found in these cultures.

\section{Aromalase activity}

Aromatase activity was first measured in 7 DIV primary cultures of whole brains from halchling males and females (1-4 d of age), incubated with ${ }^{3} \mathrm{H}-\mathrm{AE}$ for 2.5 or $24 \mathrm{hr}$. Although ${ }^{3} \mathrm{H}$-estrogens were undetected in control polylysine-coated $25 \mathrm{~cm}^{3}$ flasks that contained no cells, both $E_{1}$ and $E_{2}$ were present in large amounts when cells were present (1.01 mg of cellular protein/flask) and their identity was verified by triple recrystallization to constant specific activity (Fig. 2). In addition, radioactivity was present on the TLC plates in large amounts within $2 \mathrm{~cm}$ of the origin. We assume that this product(s) is a metabolite of estrone or perhaps estradiol since it remained in the phenolic phase and it accumulated over time (up to $73 \%$ of radioactivity in the phenolic phase after $24 \mathrm{hr}$ ) at the same time that ${ }^{3} \mathrm{H}-\mathrm{E}_{1}$ decreased to only $8.3 \%$ of the radioactivity after $24 \mathrm{hr}$. However, radioactivity from this region did not recrystallize together with estriol, and did not migrate together on TLC with the catecholestrogens, 2- or 4-hydroxy- $E_{2}$ or 2- or 4-hydroxy- $E_{1}$. Consequently, its identity remains unknown. In subsequent experi- 
Table 1. Kinetic analysis of aromatase in primary telencephalic cultures of developing zebra finches

\begin{tabular}{|c|c|c|c|c|}
\hline & \multicolumn{2}{|c|}{${ }^{3} \mathrm{H}$-androstenedione } & \multicolumn{2}{|c|}{${ }^{3} \mathrm{H}$-testosterone } \\
\hline & $\begin{array}{l}K_{m} \\
(\mathrm{nM}) \\
\end{array}$ & $\begin{array}{l}V_{\max } \\
(\mathrm{fmol} / \mathrm{min} / \\
\mathrm{mg} \text { prot })\end{array}$ & $\begin{array}{l}K_{m} \\
(\mathrm{nM}) \\
\end{array}$ & $\begin{array}{l}V_{\max } \\
\text { (fmol/min } / \mathrm{mg} \\
\text { prot) }\end{array}$ \\
\hline Exp. 1 & 15.7 & 900.0 & \multicolumn{2}{|c|}{ Not measured } \\
\hline Exp. 2 & \multicolumn{2}{|c|}{ Not measured } & 38.8 & 178.5 \\
\hline Exp. 3 & 14.1 & 176.0 & 55.0 & 1550.0 \\
\hline Exp. 4 & 18.6 & 1299.0 & 17.8 & 411.8 \\
\hline Exp. 5 & \multicolumn{2}{|c|}{ Not measured } & 177.6 & 900.0 \\
\hline Mean & 16.1 & 791.7 & 72.3 & 760.1 \\
\hline
\end{tabular}

Cultures 2 weeks (Exps. 2, 3, 5) or 3 weeks (Exps. 1, 4) in vitro were incubated for $15 \mathrm{~min}$ with increasing concentrations (2-260 nM, Exps. 1,$2 ; 1 \mathrm{nM}$ to $1 \mu \mathrm{M}$, Exps. $3,4,5)$ of ${ }^{3} \mathrm{H}-\mathrm{AE}$ or ${ }^{3} \mathrm{H}$-T in duplicate or triplicate. $K_{m}$ and $V_{\max }$ were estimated from double reciprocal (Lineweaver-Burke) plots.

ments, ${ }^{3} \mathrm{H}-\mathrm{E}_{1},{ }^{3} \mathrm{H}-\mathrm{E}_{2}$, and the unknown ${ }^{3} \mathrm{H}-\mathrm{E}$ were quantified, but only combined data for $\mathrm{E}_{1}$ and $\mathrm{E}_{2}$ was used as a measure of aromatization.

Because of the high rates of aromatization and apparent estrogen catabolism, we incubated duplicate sister wells of a single culture of zebra finch telencephalon (at 21 DIV) with $300 \mu \mathrm{l}$ of $62.5 \mathrm{~nm}{ }^{3} \mathrm{H}$-AE for $0.25,0.50,1.0,2.5,6$, or $24 \mathrm{hr}$ (Fig. 3). Although only small amounts of protein were present in each culture well $($ mean $=95.8 \mu \mathrm{g}),{ }^{3} \mathrm{H}-\mathrm{AE}$ was rapidly metabolized (Fig. 3). $E_{1}$ and $E_{2}$ accumulation under these conditions was linear for a $15 \mathrm{~min}$ incubation, reached a maximum after 2.5 $\mathrm{hr}$, and decreased thereafter because products were apparently metabolized into unknown estrogenic metabolites (Fig. 3; see also Fig. 2). Moreover after $15 \mathrm{~min}$, little or no radioactivity was present on TLC plates outside of $E_{1}$ or $E_{2}$ (not illustrated). In a separate experiment, we tested the ability of two aromatase inhibitors 1,4,6-androstatrien-3,17-dione (ATD) or fadrozole hydrochloride (CGS 16949A) (Wade et al., 1994) to block aromatization of ${ }^{3} \mathrm{H}-\mathrm{AE}(65 \mathrm{pmol} / \mathrm{ml})$. Duplicate wells were preincubated with inhibitor (1-, 10-, 100-, or 1000-fold excess ${ }^{3} \mathrm{H}-$ AE concentration) after which ${ }^{3} \mathrm{H}-\mathrm{AE}$ was added for $15 \mathrm{~min}$. Both inhibitors reduced the formation of estrogens by $>90 \%$ over control wells, fadrozole at all concentrations, and ATD at 1000-fold excess concentration (not illustrated).

Separate telencephalic cultures were then incubated for 15 min with increasing concentrations of ${ }^{3} \mathrm{H}-\mathrm{AE}$ or ${ }^{3} \mathrm{H}-\mathrm{T}$ in duplicate or triplicate $(2-260 \mathrm{nM} ; 1 \mathrm{nM}$ to $1 \mu \mathrm{M})$ (Table 1$)$. Under these conditions, $\mathrm{E}_{1}$ was the principal estrogenic product of $\mathrm{AE}$ aromatization, whereas $\mathrm{E}_{2}$ was the principal estrogenic product of $\mathrm{T}$ aromatization. $\mathrm{E}_{2}$ derived from $\mathrm{T}$ was verified by triple recrystallization $\left(584.6 / 629.1 \mathrm{dpm}_{\text {crystals }} / \mathrm{dpm}_{\text {mother liquor }}, 86.1 \%\right.$ recovery). Analyses of saturation and reaction kinetics for three experiments (Table 1) indicate that aromatase had high affinity for the AE substrate (mean $K_{m}=15.7 \mathrm{~nm}$ ) and was present in very high abundance (mean $V_{\max }=791.8 \mathrm{fmol} / \mathrm{min} / \mathrm{mg}$ protein). By contrast, in four separate experiments with ${ }^{3} \mathrm{H}-\mathrm{T}$ as substrate (Table 1), the $K_{m}$ for aromatase varied from 17.8 to $177.6 \mathrm{nM}$ $($ mean $=72.3 \mathrm{~nm})$; mean $V_{\max }=760.1 \mathrm{fmol} / \mathrm{min} / \mathrm{mg}$ protein $)$.

\section{The effect of age of cultures on aromatase activity and on the} cellular composition of telencephalic cultures

Because initial immunohistochemical observations suggested that the proportion of neurons in the telencephalic cultures de-
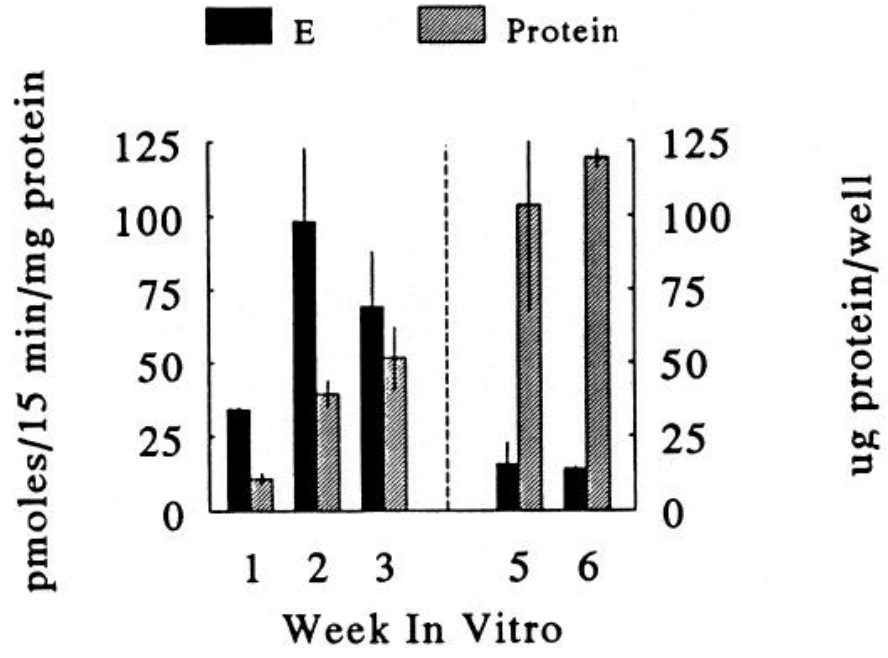

Figure 4. Aromatase activity in cultures of developing zebra finch telencephalon as a function of age in vitro. Triplicate wells were incubated with ${ }^{3} \mathrm{H}-\mathrm{AE}$ for 15 min after $1,2,3,5$, or 6 weeks in vitro. The samples for weeks 1,2 , and 3 represent different wells of cultures prepared on the same date from a single suspension of telencephalic cells and aromatase activity quantified in a single assay and analyzed statistically as a group. Data were analyzed by one-way ANOVA: ${ }^{*}, F_{(2.6)}=$ $9.19 ; p<0.02$. The values for weeks 5 and 6 represent two other telencephalic culture preparations and were not part of the statistical analysis.

clined as cultures aged, we were interested in determining how culture age influenced aromatase activity. We added ${ }^{3} \mathrm{H}-\mathrm{AE}$ for 15 min to triplicate wells of cultures after $1,2,3,5$, or 6 weeks in vitro. The samples for weeks 1,2 , and 3 represent different wells of cultures prepared on the same date from a single suspension of telencephalic cells. Following incubation with ${ }^{3} \mathrm{H}-$ $\mathrm{AE}$, the media from these experiments were frozen so that aromatase activity from the three ages could be determined in a single assay, and analyzed statistically as a group. The values for weeks 5 and 6 , which represent two other telencephalic culture preparations, are included for comparison (Fig. 4), but were not part of the statistical analysis. Cells in these cultures continued to proliferate between 1 and 3 weeks of age as indicated by the significant increase in protein content $\left(F_{(2,6)}=9.19 ; p<\right.$ 0.02 ) (Fig. 4), and most likely up to at least 6 weeks in vitro. Aromatase activity (per mg protein) remained high up to 3 weeks in vitro, but appeared to decline thereafter [the apparent increase between 1 to 2 weeks was not statistically significant $\left(F_{(2,6)}=\right.$ $3.22, p=0.11)]$. Nevertheless, even after 6 weeks in vitro, cells continued to synthesize estrogens at an extremely high rate (14.0 $\mathrm{pmol} / 15 \mathrm{~min} / \mathrm{mg}$ protein).

Sister wells of the tissue cultured for 1,2 , and 3 weeks were labeled in immunohistochemical experiments. Visual inspection of the incidence of cells recognized by anti-MAP5 (Fig. 5) suggested that despite the overall increase in protein (and hence presumably numbers of cells in these cultures), the numbers of neurons declined in the first 3 weeks in vitro (Fig. 4). For quantitative assessment, the numbers of neurons and glial cells were counted over an area of $\geq 1.3 \mathrm{~mm}^{2}$ in sister wells labeled using the anti-vimentin antibody. The percentage of neurons declined from $43.4 \%$ at week 1 to $35.7 \%$ at week 2 , to $4.2 \%$ at week 3 . The persistence of aromatase into the third week, despite a large decline in the number of neurons present in the cultures, supports the idea that aromatase is not exclusively expressed in neurons. 

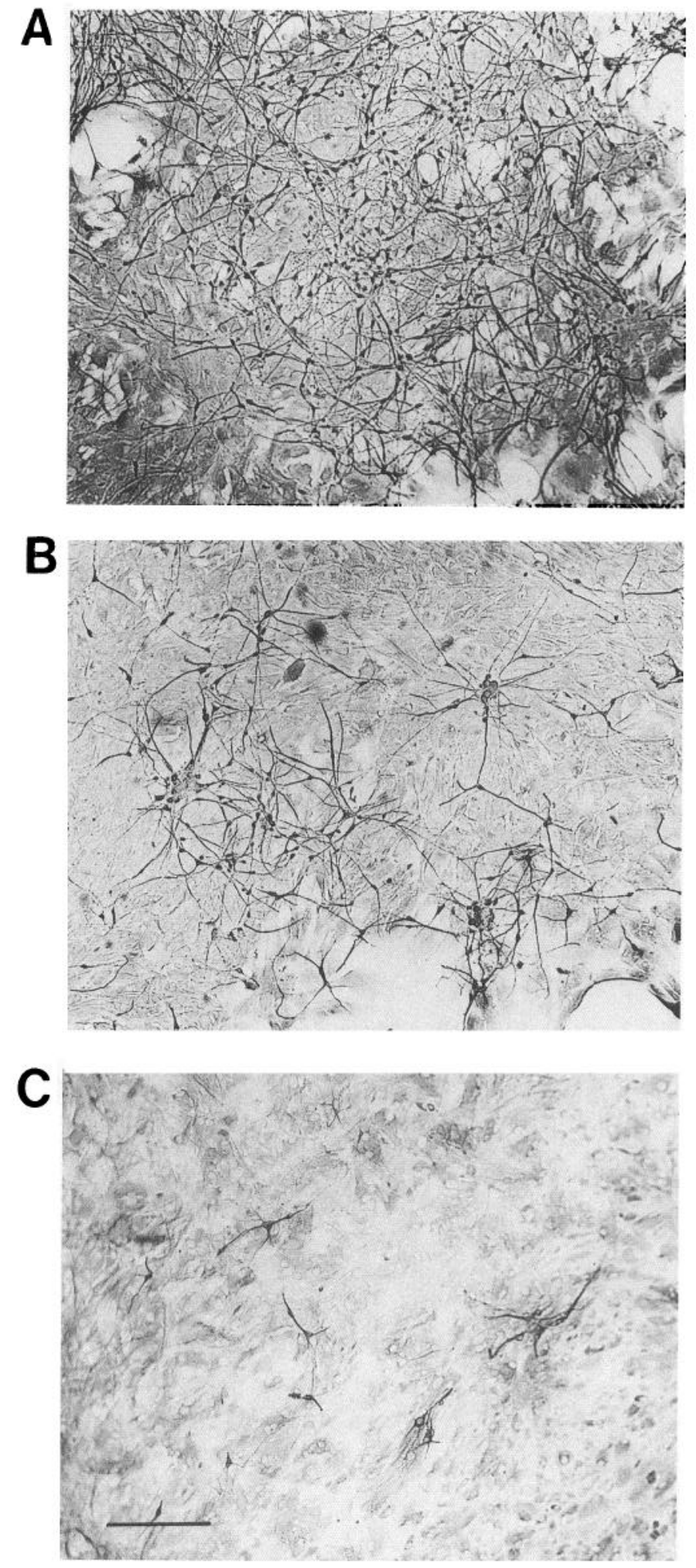

Figure 5. MAP5 immunoreactivity in mixed neuronal-glial cultures. This antibody labeled neurons exclusively. The three photos show sister cultures used for the data in Figure 4: top, after 1 week in vitro; middle, after 2 weeks; bottom, after 3 weeks. These photos demonstrate the apparent decline in the incidence of neurons with age of the cultures. The percentage of neurons was $43.4 \%$ at 1 week, $35.7 \%$ at 2 weeks, and $4.2 \%$ at 3 weeks.

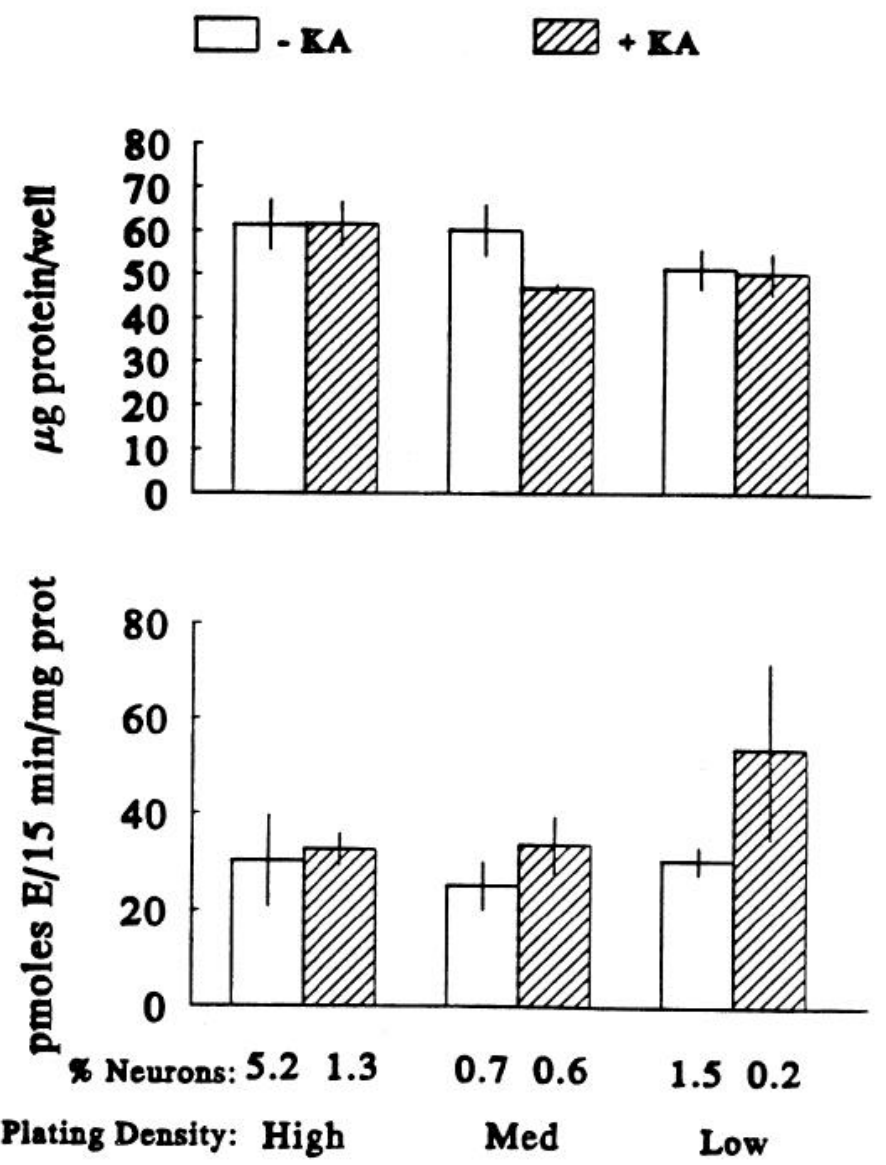

Figure 6. Effects of kainic acid $(K A)$ treatment and plating density on protein content $\left(\mu \mathrm{g} /\right.$ well; top) and aromatase activity (pmol $\mathrm{E}_{1}+\mathrm{E}_{2} / 15$ $\mathrm{min} / \mathrm{mg}$ protein; bottom) on developing zebra finch telencephalic cell cultures. KA treatment $(10 \mathrm{~mm})$ was initiated $14 \mathrm{~d}$ in vitro and lasted 7 d. Plating density: High, 10 paired telencephalons $/ 50 \mathrm{ml}$ medium; $\mathrm{Med}$, half concentration of $\mathrm{High}$; Low, half concentration of $\mathrm{Med} ; n=$ 3 wells/plating density/treatment group. Sister wells of tissue cultured on glass coverslips at the same plating densities received similar KA treatments. The percentage of neurons present in these cultures was estimated by immunohistochemical analysis of coverslips using antivimentin antibodies to count cell bodies of neurons and Hoechst dye to count nuclei of cells.

\section{Aromatase activity in neuron-deficient telencephalic cultures after treatment with neurotoxin}

To test this idea further, we treated some cultures with the neurotoxin kainic acid in an attempt to kill neurons. In three separate experiments, cultures were prepared from telencephalons of 1-5-d-old zebra finches at one of three plating densities (High, 10 telencephalons per $50 \mathrm{ml}$ medium; Medium, half concentration of High; or Low, one-fourth concentration of High. After 2 weeks in vitro, cultures were treated continuously with kainic acid $\left(1 \times 10^{-2} \mathrm{M}\right)$ (media changed daily or on alternate days) for $4 \mathrm{~d}$ (Exp. 1) or 7 days (Exps. 2 and 3). The effects of kainate and plating density were assessed by measuring the amount of protein per culture well and by counting the numbers of neurons.

Neurons were always a minor component of these mixed cultures and were generally present in lower numbers at the lowest plating densities. For example, in untreated culture wells of experiment 3 (Fig. 6), neurons accounted for $5.2 \%, 0.7 \%$, and $1.5 \%$ of the cell population at high, medium and low plating 
Table 2. Effect of kainic acid and cellular plating density on aromatase activity in primary telencephalic cultures of developing zebra finches

\begin{tabular}{|c|c|c|c|c|c|c|}
\hline & High & & Medium & & Low & \\
\hline & - & + & - & + & - & + \\
\hline Experiment $1(N)$ & 6 & 6 & 6 & 6 & 4 & 5 \\
\hline \# Neurons & 9.5 & 5.2 & 8.3 & 2.1 & 1.03 & 0.97 \\
\hline Protein $(\mu \mathrm{g} /$ well $)$ & $78.1 \pm 9.5$ & $74.4 \pm 19.5$ & $79.3 \pm 0.44$ & $45.4 \pm 1.5$ & $40.8 \pm 0.4$ & $45.4 \pm 1.5$ \\
\hline Aromatase $(\mathrm{pmol} / 150 \mathrm{~min} / \mathrm{mg} \mathrm{prot})$ & $99.4 \pm 16.2$ & $119.5 \pm 20.1$ & $123.2 \pm 26.5$ & $121.6 \pm 23.2$ & $189.5 \pm 54.0$ & $85.2 \pm 19.7$ \\
\hline Experiment $2(N)$ & 3 & 3 & 3 & 3 & 3 & 3 \\
\hline$\%$ Neurons & $1.2 \%$ & $0.6 \%$ & $6.2 \%$ & $1.1 \%$ & $0.3 \%$ & $0.2 \%$ \\
\hline Protein $(\mu \mathrm{g} /$ well $)$ & $94.5 \pm 8.9$ & $60.0 \pm 5.4$ & $90.0 \pm 4.8$ & $50.7 \pm 5.2$ & $61.3 \pm 1.2$ & $45.0 \pm 7.8$ \\
\hline Aromatase $(\mathrm{pmol} / 150 \mathrm{~min} / \mathrm{mg}$ prot $)$ & $28.5 \pm 5.4$ & $57.9 \pm 5.8$ & $35.1 \pm 7.4$ & $58.0 \pm 5.3$ & $33.8 \pm 3.1$ & $59.5 \pm 9.6$ \\
\hline
\end{tabular}

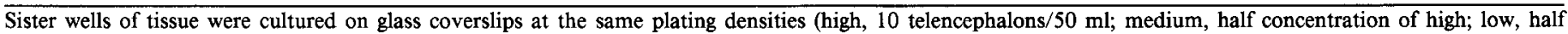

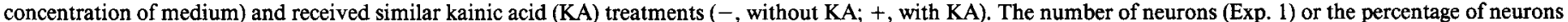

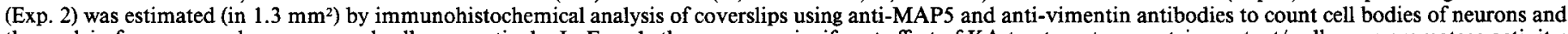

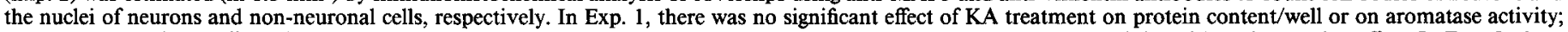

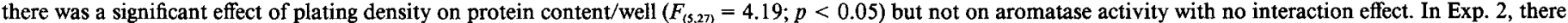

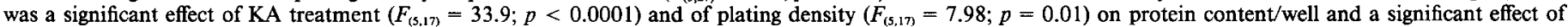
kainic acid treatment $\left(F_{5,17)}=24.6 ; p<0.0003\right)$ but not plating density on aromatase activity, with no interaction effects.

$N$, number of wells/group.

density, respectively (Table 2). Kainic acid further reduced the number of ncurons present in thesc culturcs. When averaged over the three experiments, neuron numbers were reduced by $57 \%, 55 \%$, and $48 \%$ in high, medium, and low plating densities, respectively. Nevertheless, kainic acid did not always reduce the total protein content (Table 2, Fig. 6, top), suggesting that glia continue to proliferate in the presence of kainic acid.

Aromatase activity was not reduced by treatments that reduced neuronal numbers. For example, in experiment 2 (Table 2), although neuron numbers were reduced at low plating densities and varied as much as $\mathbf{3 0 - f o l d ~ a s ~ a ~ f u n c t i o n ~ o f ~ p l a t i n g ~ d e n s i t y , ~ a r o - ~}$ matase activity was relatively unaffected and remained high $(\sim 32.5$ $\mathrm{pmol} / 15 \mathrm{~min} / \mathrm{mg}$ protein). Similarly, although kainic acid dramatically reduced neuron numbers in all experiments, it had relatively little effect on aromatase activity. In experiments 1 and 3, there was no significant effect of kainic acid on aromatase activity at any plating density (Fig. 5, Table 2). In experiment 2, kainic acid reduced neuron numbers by as much as $81 \%$, and increased aromatase activity significantly at all plating densities. The loss of protein in the latter experiment suggests that glia did not replace the neurons lost to kainic acid. Moreover, the increase in aromatase activity (per mg protein) suggests that cells expressing aromatase activity were enriched by kainic acid treatment. In this latter experiment, in which aromatase activity was extremely high in the virtual absence of neurons ( $58.5 \mathrm{pmol} / 15 \mathrm{~min} / \mathrm{mg}$ protein), we confirmed the identity of the estrogenic products by recrystallization (for $E_{1}$ and $E_{2}$, respectively, 523/530 and 378/411 $\mathrm{dpm}_{\text {crystals }} / \mathrm{dpm}_{\text {mother liquor, }}, 95 \%$ and $100 \%$ recovery).

\section{Aromatase activity in neuron-enriched and glia-enriched cultures}

Aromatase activity was also measured in glia-enriched cultures or in neuron-enriched cultures. Visual inspection with phasecontrast microscopy showed neurons to be absent from gliaenriched cultures (not shown). By contrast, the neuron-enriched cultures were not free of glia, but neurons were always present in equal or greater numbers than were glia. Two $75 \mathrm{~cm}^{2}$ flasks containing glia and one enriched with neurons were incubated with ${ }^{3} \mathrm{H}$-AE ( $65 \mathrm{~nm}$ ) for $3 \mathrm{hr}$. Estrogens were formed in large amounts in all three flasks $(54.4 \mathrm{pmol} / \mathrm{mg}$ glial protein; 22.7 $\mathrm{pmol} / \mathrm{mg}$ neuronal-enriched protein).

\section{Northern analysis and in situ hybridization analysis of aromatase in telencephalic cell cultures}

To determine if the aromatase enzyme activity was reflected in aromatase mRNA levels, in situ hybridization was performed on the primary mixed cultures. Typical results are shown in Figure 7, where aromatase mRNA could be detected clearly in neuronal cell bodies and their processes. In addition we also observed large clusters of label in these cultures that varied in size and intensity, but which we could not clearly assign to specific cell types, because individual cells could not be resolved in the dense glial mat.

Accordingly, we prepared glial cultures that were free of neurons and in which glia could be resolved as individual cells, and we examined these cultures by in situ hybridization histochemistry (Fig. 7). In these cultures, aromatase mRNA was detected clearly within the cytoplasm of these cells, but with a heterogeneous appearance. Although low levels of aromatase mRNA could be seen as uniform labeling throughout the cells, much of the labeling appeared punctate. Thus, these in situ hybridization studies indicate that aromatase mRNA is present in these non-neuronal cells, consistent with the finding of aromatase activity in these cultures.

To further characterize the aromatase mRNA giving rise to the in situ hybridization signal, total RNA was prepared from both the neuron-enriched and glia-enriched cultures and subjected to Northern blot analysis (Fig. 8A). The probe for zebra finch aromatase recognized a band of approximately $5.3 \mathrm{~kb}$ in lanes loaded with total mRNA from both neuron- and gliaenriched cultures, and from whole ovary. When the amounts of total RNA loaded in each lane were taken into consideration, the steady-state levels of aromatase mRNA present in the neuron-enriched cultures were significantly higher than the steady state levels present in the glia-enriched cultures. This is in sharp contrast to the levels of enzyme activity present in the two cell culture preparations, where activity measured in glia-enriched cultures was about twofold greater than in neuron-enriched cultures. In a second experiment, we loaded equal amounts $(15 \mu \mathrm{g})$ of total RNA from glia-enriched and neuron-enriched cultures (Fig. 8B). In this case, neuron-enriched cultures contained 616-fold more aromatase mRNA after scanning two separate 
A
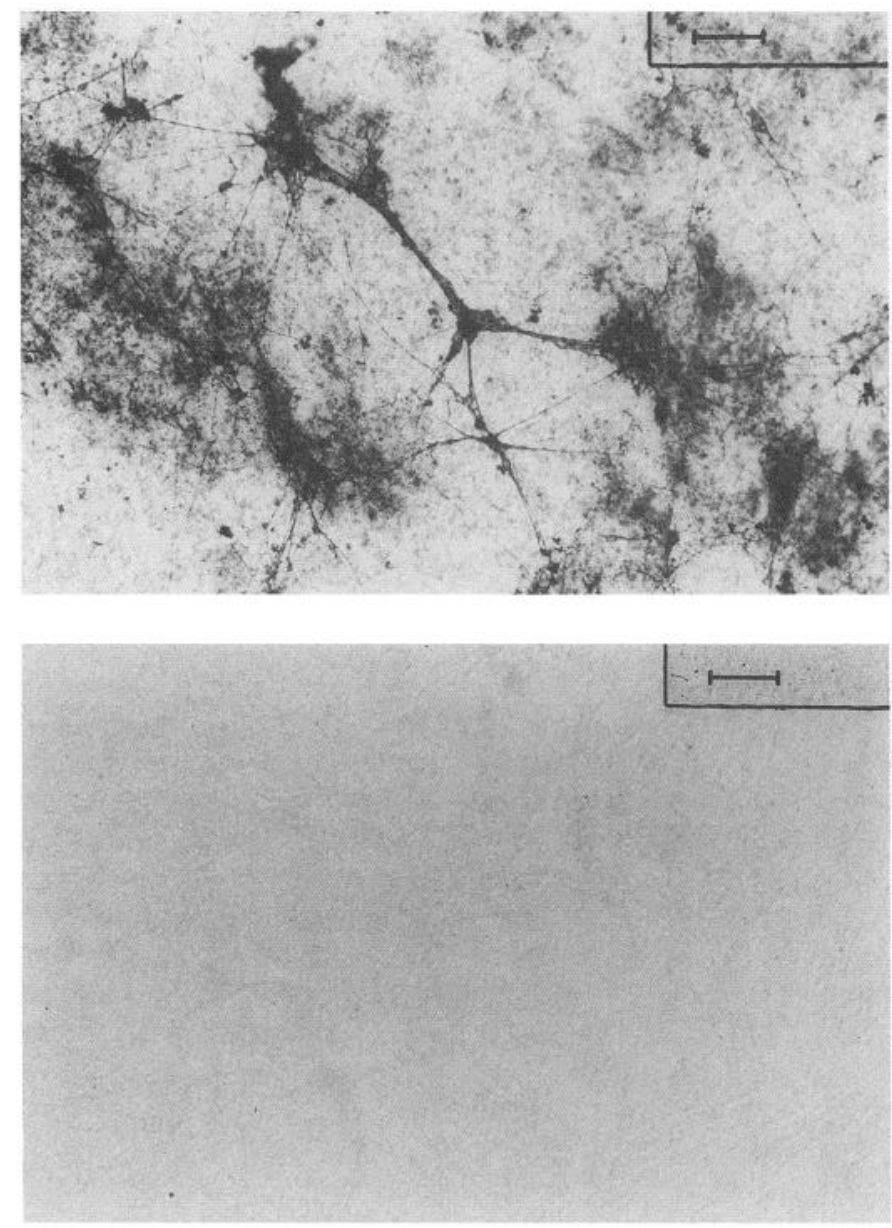

B
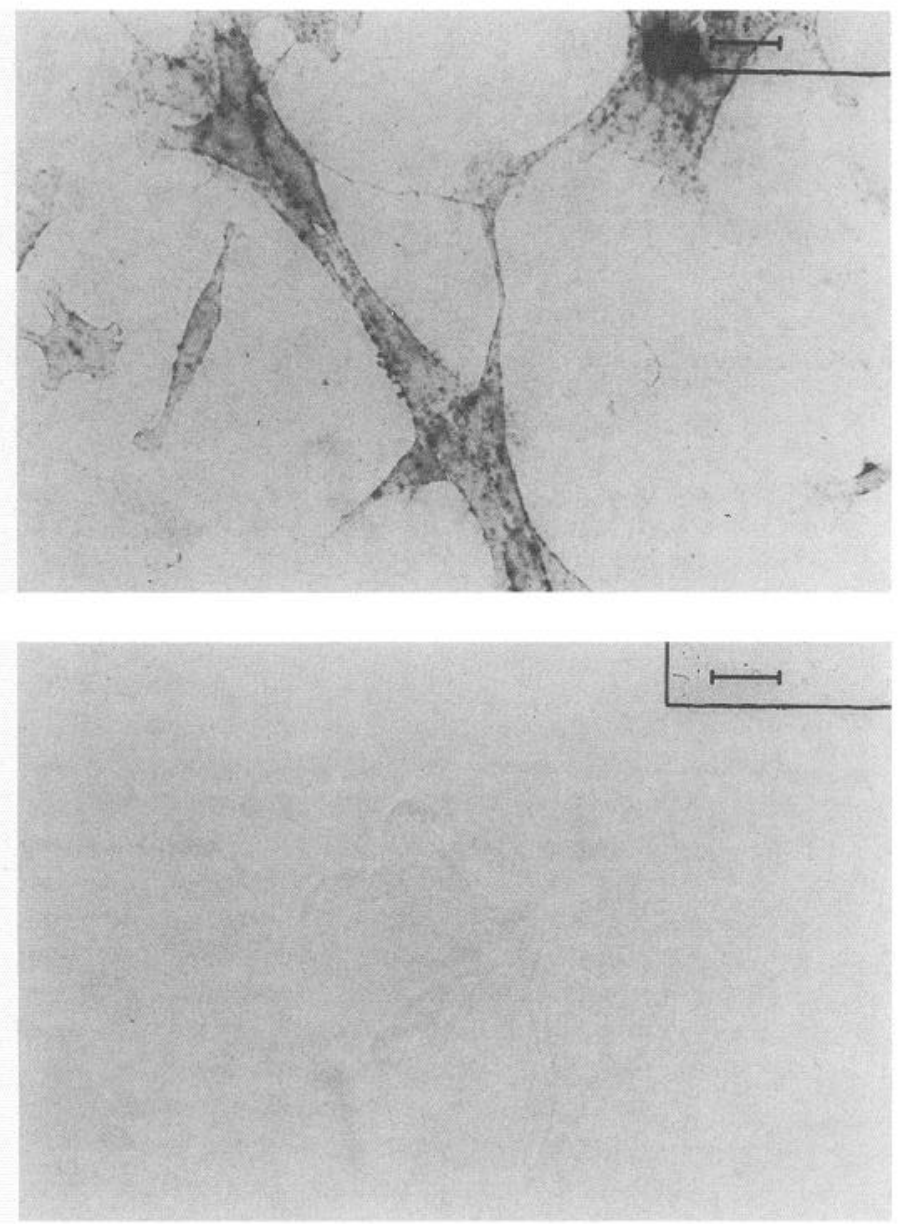

D

Figure 7. In situ hybridization of a digoxigenin-labeled aromatase cDNA probe with cells in mixed-primary cultures of zebra finch telencephalon (left) or glia-enriched cultures (right). Neurons were clearly labeled in mixed-cultures (top left), as were unidentified large cells in the underlying glial mat. Presumably, the unidentified labeled cells in mixed-primary cultures were glia, since individual glia were clearly labeled when they were cultured free of neurons and at a lower plating density (top right). When the cDNA probe was eliminated from the reaction (bottom), both neurons (bottom left) and glia (bottom right) remained unlabeled. Scale bars, $26 \mu \mathrm{m}$.

autoradiograms (exposed for different times) with a MicroScan 1000 2D Gel Analysis System (Technology Resources Inc, Nashville, TN).

\section{Discussion}

These studies provide several lines of evidence that in primary cultures of the developing zebra finch telencephalon, aromatase is expressed in both neurons and non-neuronal cells, presumably astrocytes. Evidence that aromatase is expressed in non-neuronal cells is derived from several sources. First, aromatase was expressed at unusually high levels in mixed cultures when nonneuronal cells predominated, accounting for greater than $90 \%$ of all cells. Second, as the cultures aged, levels of aromatase did not decrease in correlation with the decline in the incidence of neurons. Third, aromatase was expressed at comparable levels at various plating densities, independent of neuronal numbers. Fourth, reducing or eliminating neurons by treatment with a neurotoxin failed to reduce aromatase activity. Fifth, aromatase activity persisted at high levels in glial cultures in which neurons were removed physically by vigorous shaking. Sixth, a cDNA probe encoding zebra finch aromatase hybridized to RNA on Northern blots extracted from similar glial preparations. Finally, non-neuronal cells, with the morphology of astrocytes, stained positively for aromatase mRNA after in situ hybridization with the digoxigenin-labeled zebra finch specific aromatase probe. Evidence that aromatase is expressed in neurons is also derived from several sources. First, aromatase activity is present in cultures enriched with neurons by growing cells in medium optimally suited for neuronal growth. Second, the zebra finch aromatase cDNA hybridized strongly to small amounts of RNA from these neuron-enriched cultures, relatively more strongly than to RNA from pure glial cultures. Finally, neurons were darkly labeled after in situ hybridization with the zebra finch digoxigenin-labeled aromatase probe.

The presence of aromatase in neurons is not unexpected. Aromatase is usually expressed most abundantly in limbic brain structures, where activity is thought to be located in neurons. This conclusion is derived from three principal lines of evidence. 


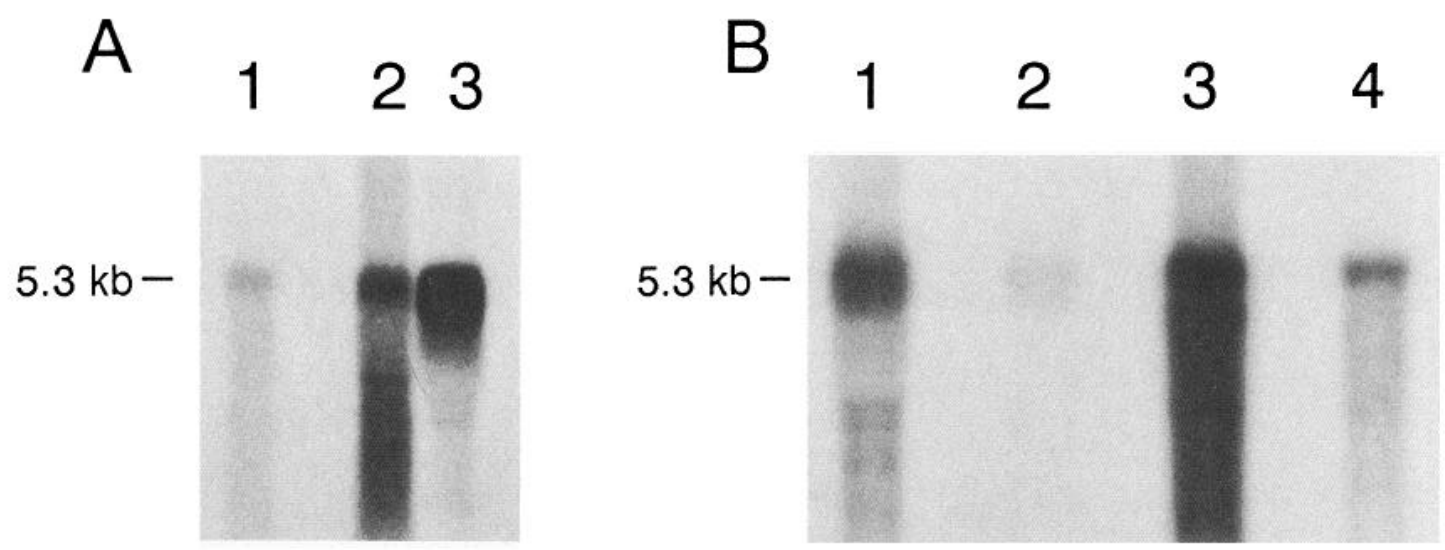

Figure 8. A, Aromatase expression in glia-enriched or neuron-enriched cultures of zebra finch telencephalon or in ovarian or telencephalic homogenates. Aromatase mRNA of about $5.3 \mathrm{~kb}$ was detected in all tissues on Northern blots using a full-length $3.2 \mathrm{~kb}$ zebra finch aromatase cDNA probe. RNA yields of the neuron-enriched cultures were significantly lower than glial cultures; this blot contained $2 \mu \mathrm{g}$ of total RNA from the neuron-enriched cultures (lane 1) and $20 \mu \mathrm{g}$ of total RNA from glia-enriched cultures (lane 2) and ovary (lane 3). B, When equal amounts of mRNA were loaded onto gels, aromatase mRNA was measured to be 6-16-fold more abundant in neurons (lane 1) than in glia (lane 2). For comparison, we also ran poly ${ }^{+}$RNA (3 $\mu \mathrm{g}$ each) isolated from homogenates of ovary (lane 3 ) and whole female telencephalon (lane 4).

First, when monolayer cultures of fetal rat hypothalamus are treated with the neurotoxin kainic acid, there is a substantial decline in aromatase activity and in cells exhibiting neuronal morphology and the neuronal marker Substance $P$, whereas nonneuronal cells and the glial marker, glutamine synthetase, are relatively unaffected (Canick et al., 1986). Second, aromatase is enriched in purified synaptosomal preparations of the goldfish brain (Mak et al., 1985) and quail hypothalamus (Schlinger and Callard, 1989), suggesting that it is present in nerve terminals. Finally, aromatase immunoreactivity is detectable in cells presumed (on the basis of morphological criteria) to be neurons in mammalian and avian brain sections (Shinoda et al., 1989a,b; Balthazart et al., 1990, 1991a; Sanghera et al., 1991). In quail hypothalamus-preoptic area, aromatase immunoreactivity is found in synaptic terminals (Naftolin et al., 1990).

Aromatase mRNA was apparently distributed throughout neuronal somata and also in neuritic processes. This latter observation agrees with the aforementioned observations of aromatase protein in processes and nerve terminals (Mak et al., 1985; Schlinger and Callard, 1989; Balthazart et al., 1990; Naftolin et al., 1990). These data lend additional support for the view that estrogen synthesis in processes and in terminals are important properties of at least some neurons. Because cells that express aromatase do not always express estrogen receptors (Balthazart et al., 1991b), the site of action of estrogen synthesized in such cells may be on processes, terminals, or postsynaptic membranes of the same or other cells. Estrogen receptor immunoreactivity has also been detected in these same subcellular components (Blaustein et al., 1992), suggesting that estrogen acts outside of cell nuclei. Alternatively, one or more neurons expressing nuclear estrogen receptor may be provided with estrogens if they are near or contacted by aromatase-positive processes or terminals. The mechanisms for supply of estrogen to estrogen-sensitive neural circuits remains to be fully elucidated.

The presence of aromatase activity in non-neuronal cells represents a new cellular localization for this enzyme in the vertebrate brain. Interestingly, despite measurable aromatase activity in zebra finch telencephalon (as well as in rat and monkey preoptic area), immunohistochemical studies have failed to label cell bodies in these brain regions (Shinoda et al., 1989a,b; Balthazart et al., 1990; Sanghera et al., 1991) using antibodies raised against human placental aromatase (Shinoda et al., 1989a,b; Balthazart et al., 1991a) or against a synthesized peptide fragment of a highly conserved region of the aromatase protein sequence (identical in rat, human, chicken) (Sanghera et al., 1991). It is possible that aromatase immunoreactivity is only detectable when present at very high concentrations in a few cells. The absence of immunoreactivity in rat and monkey preoptic area or zebra finch telencephalon may represent low enzyme abundance per cell, despite its presence in numerous individual cells. A second possibility is that aromatase may be present in axons or terminals within these brain regions, derived from neurons whose somata lie elsewhere (Shinoda et al., 1989a,b; Naftolin et al., 1990; Balthazart et al., 1991a). A third possibility is that aromatase may exist in brain in several forms, not all of which are recognized by the antibodies. For example, aromatase in the songbird brain may be expressed by a distinct form of the enzyme within neurons in limbic brain and a second form within non-neuronal cells in the telencephalon. Further studies are required to resolve this issue.

Aromatase was extremely active in these primary cultures, whether enriched in neurons or in glia. For example, activity ranged from 0.13 to $6.67 \mathrm{pmol}$ estrogen $/ \mathrm{min} / \mathrm{mg}$ protein, levels that greatly exceed the activities previously detected in cell cultures of fetal rat hypothalamus, adult turtle forebrain or adult teleost preoptic area/hypothalamus $(0.27,1.1,18.0$ pmol estrogen $/ 24 \mathrm{hr} / \mathrm{mg}$ cell protein, respectively) (Canick et al., 1977, 1986; Callard, 1980, 1984). Moreover, the activity seen in cell culture is more than 100 -fold and 20 -fold greater than that measured in homogenates or microsomal preparations, respectively, of developing zebra finch telencephalon (Schlinger and Arnold, 1992a). Presumably, this high activity results from enrichment in vitro of cell types that express aromatase activity. It is also possible that regulatory mechanisms present in the telencephalon in vivo are altered in homogenates or in cultures, causing the observed differences in activity. For example, products secreted by neurons or other cells to inhibit the expression of aromatase in glia might be reduced or absent in these cultures. Circulating sex steroids (Roselli et al., 1984; Hutchison and Steimer, 1986; Roselli and Resko, 1986; Pasmanik et al., 1988) or their metabolites (Schumacher et al., 1991) and cAMP (Callard, 1981) have all been shown to influence aromatase expres- 
sion in limbic brain. However, we know little about the regulation of aromatase in the developing zebra finch telencephalon. For example, castration reduces and $T$ treatment restores aromatase activity in the zebra finch preoptic area of adult males, but has no effect on aromatase in microdissected regions of the telencephalon (Vockel et al., 1990). It will be important to determine whether such regulatory factors exist and how they might influence the estrogen synthetic capacity of the telencephalic glia.

The presence of aromatase in non-neuronal cells suggests that these cells may be a site of estrogen action. Neurons are generally considered the primary estrogen targets in brain since sex steroid receptors are most abundant in neurons (Pfaff and Keiner, 1973; Gahr et al., 1987) and most studies of steroid action in brain have involved measurements of neurons (McEwen et al., 1982; Pfaff, 1983; Arnold and Gorski, 1984). Nevertheless, there is evidence for actions of estrogens on glia. For example, estrogen treatment increases the number of processes of GFAP-positive cells (presumably astrocytes) in the globus pallidus and hippocampus of adult female rats (Tranque et al., 1987; Luqui et al., 1993) and in primary cultures of fetal rat hypothalamus (GarciaSegura et al., 1989). Moreover, there is evidence for estrogen receptors in glial and ependymal cells (Pfaff and Keiner, 1973; Jung-Testas et al., 1992; Langub and Watson, 1992). Previous studies have found estrogen-concentrating or estrogen receptor immunoreactive neurons in several telencephalic structures in the songbird brain (Gahr et al., 1987; Nordeen et al., 1987; Gahr, 1990), but have not reported estrogen receptors in glia.

We were interested in the observation that while aromatase activity and aromatase mRNA were present in both glia-enriched and neuron-enriched cultures, mRNA abundance did not correspond with relative enzyme activity in these cellular preparations. Specific enzyme activity in the glia-enriched cultures was approximately twofold greater than in neuron-enriched cultures, but the amounts of aromatase mRNA were 6-16-fold lower. We cannot account for this discrepancy, but it suggests that aromatase mRNA is less stable in glia than in neurons, or that the aromatase protein is more stable in glia, or that rates of translation of the aromatase mRNA in the two cell types are different. This implies that different mechanisms are operative to regulate aromatase in these discrete cell types, perhaps contributing to developmental and regional changes seen in the activity of the enzyme (Vockel et al., 1990; Schlinger and Arnold, 1991, 1992a).

It is well established that the telencephalic neural circuitry underlying singing behavior is highly sensitive to estrogen. Not only does exogenous estrogen treatment during early development cause extensive masculinization of the song system (Gurney and Konishi, 1980), but estrogen receptor immunoreactive cells, assumed to be neurons, are present near the neural regions controlling song (Gahr et al., 1987; Nordeen et al., 1987; Gahr and Konishi, 1988). Furthermore, it is likely that the active estrogen is formed in the brain (Schlinger and Arnold, 1992a,b). Although aromatase may also be present in neurons, it is interesting to speculate that in addition, estrogens formed in nonneuronal cells might be transported to neurons, where they act to organize brain circuitry. Since estrogens formed in brain enter the general circulation (Schlinger and Arnold, 1992, 1993), it is likely that they also enter nearby steroid-sensitive neurons.

We are impressed by the rate of uptake, conversion and release of sex steroids by these cultures. As discussed above, rates of aromatization per minute in these cultures were comparable to rates per hour or day in brain cell cultures of other vertebrates (Canick et al., 1977, 1986; Callard, 1980, 1984). It will be interesting to determine whether additional cellular mechanisms are present to increase the velocity of these reactions. For example, are there particularly efficient mechanisms for cellular transport of steroids? If so, does this mechanism also account for the efficient release of estrogen from the brain and for the brain's role as the primary source of estrogen found in the circulation of adult male zebra finches (Schlinger and Arnold, 1992b, 1993)?

The present data also raise the question of the importance of estrogen metabolism in sexual differentiation of the zebra finch telencephalon. The presence of aromatase, in non-neuronal cells in or near brain regions controlling song, suggests that these cells may be involved in sexual differentiation of this behavior. However, since hatchling males and females possess similar levels of telencephalic aromatase and aromatizable androgens in blood (Adkins-Regan et al., 1990; Schlinger and Arnold, 1992a), it may be that estrogens in brain are differentially activated in males or inactivated in females. The present data, that estradiol and estrone are themselves metabolized in these cultures at longer incubation times, confirm our previous studies in tissue homogenates indicating that estrogen metabolism in the zebra finch telencephalon is quantitatively important (Schlinger and Arnold, 1992a). It will be important to establish the identity of products of estrogen metabolism before we can ask whether these conversions are linked to sexual differentiation of the brain.

The presence of aromatase in non-neuronal cells from the developing zebra finch telencephalon is a fascinating new development in our efforts to understand the hormonal basis of sexual differentiation of the zebra finch song system. Although these results also indicate a neuronal localization for aromatase activity, they potentially provide a new view of how estrogens may be supplied to estrogen-sensitive neural circuits and may help account for the capacity of the songbird brain to secrete estrogen into the general circulation. Moreover, it will be important to determine whether non-neuronal cells are themselves sites of estrogen action. The high expression of aromatase in these cell cultures helps in our efforts to explore properties of this enzyme, its regulation, its interaction with other steroid synthetic or metabolic enzymes, and its role in neural development.

\section{References}

Adkins-Regan E, Abdelnabi M, Mobarak M, Ottinger MA (1990) Sex steroid levels in developing and adult male and female zebra finches (Poephila guttata). Gen Comp Endocrinol 78:93-109.

Alvarez-Buylla A, Buskirk D, Nottebohm F (1987) Monoclonal antibody reveals radial glia in adult avian brain. J Comp Neurol 264: $159-170$.

Amur-Umarjee SG, Dasu RG, Campagnoni AT (1990a) Temporal expression of myelin-specific components in neonatal mouse brain cultures: evidence that $2^{\prime}, 3^{\prime}$-cyclic nucleotide 3 '-phosphodiesterase appears prior to galactocerebroside. Dev Neurosci 12:251-262.

Amur-Umarjee SG, Hall L, Campagnoni AT (1990b) Spatial distribution of mRNAs for myelin protcins in primary cultures of mousc brain. Dev Neurosci 12:263-272.

Amur-Umarjee SG, Phan T, Campagnoni AT (1993) Myelin basic protein mRNA translocation in oligodendrocytes is inhibited by astrocytes in vitro. J Neurosci Res 36:99-110.

Arnold AP (1985) Gonadal steroid-induced organization and reorganization of neural circuits involved in bird song. In: Synaptic plasticity and remodeling (Cotman C, ed), pp 263-285. New York: Guilford.

Arnold AP, Gorski RA (1984) Gonadal steroid induction of structural 
sex differences in the central nervous system. Annu Rev Neurosci $7: 413-442$.

Arnold AP, Amur-Amurjee A, Campagnoni A, Schlinger BA (1992) Glia express high levels of aromatase in cultures of developing zebra finch telencephalon. Soc Neurosci Abstr 18:231.

Balthazart J, Foidart A, Surlemont C, Vockel A, Harada N (1990) Distribution of aromatase in the brain of the japanese quail, ring dove and zebra finch: an immunohistochemical study. J Comp Neurol 301 : 276-288.

Balthazart J, Foidart A, Surlemont, Harada N (1991a) Distribution of aromatase-immunoreactive cells in the mouse forebrain. Cell Tissue Res 263:71-79.

Balthazart J, Foidart A, Surlemont C, Harada N (1991b) Neuroanatomical specificity in the co-localization of aromatase and estrogen receptors. J Neurobiol 22:143-157.

Bignami A, Raju T, Dahl D (1982) Localization of vimentin, the nonspecific intermediate filament protein, in embryonal glia and in early differentiating neurons. Dev Biol 91:286-295.

Blaustein JD, Olster DH (1989) Gonadal steroid hormone receptors and social behaviors. In: Advances in comparative and environmental physiology, Vol 3 (Balthazart J, ed). Berlin: Springer.

Blaustein JD, Lehman MN, Turcotte JL, Greene G (1992) Estrogen receptors in dendrites and axon terminals in the guinea pig hypothalamus. Endocrinology 131:281-290.

Bradford MM (1976) A rapid and sensitive method for quantitation of microgram quantities of protein utilizing the principle of protein binding. Anal Biochem 72:248-254.

Callard GV (1981) Aromatization is cyclic AMP-dependent in cultured brain cells. Brain Res 204:461-464.

Callard GV (1984) Aromatization in brain and pituitary: an evolutionary perspective. In: Metabolism of hormonal steroids in neuroendocrine tissues (Celotti F, Naftolin F, Martini L, eds), pp 79102. New York: Raven.

Canick JA, Vaccaro DE, Ryan KJ, Leeman SE (1977) The aromatization of androgens by primary monolayer cultures of fetal rat hypothalamus. Endocrinology 100:250-253.

Canick JA, Vaccaro DE, Livingston EM, Leeman SE, Ryan KJ, Fox TO (1986) Localization of aromatase and $5 \alpha$-reductase to neuronal and non-neuronal cells in the fetal rat hypothalamus. Brain Res 372 : 277-282.

Chomczynski P, Sacchi N (1987) Single-step method of RNA isolation by acid guanidinium thiocyanate-phenol-chloroform extraction. Anal Biochem 162:156-159.

Cochard P, Paulin D (1984) Initial expression of neurofilaments and vimentin in the central and peripheral nervous system of the mouse embryo in vivo. J Neurosci 4:2080-2094.

Gahr M (1990) Delineation of a brain nucleus: comparisons of cytochemical, hodological, and cytoarchitectural views of the song control nucleus HVC of the adult canary. J Comp Neurol 294:30-36.

Gahr M, Konishi M (1988) Developmental changes in estrogen-sensitive neurons in the forebrain of the zebra finch. Proc Natl Acad Sci USA 85:7380-7383.

Gahr M, Flugge G, Guttinger H-R (1987) Immunocytochemical localization of estrogen-binding neurons in the songbird brain. Brain Res 402:173-177.

Garcia-Segura LM, Torres-Aleman 1, Naftolin F (1989) Astrocytic shape and glial fibrillary acidic protein immunoreactivity are modified by estradiol in primary rat hypothalamic cultures. Brain Res 47:298302.

Gurney ME, Konishi M (1980) Hormone-induced sexual differentiation of brain and hehavior in zebra finches. Science 208:1380-1382.

Hutchison JB, Steimer Th (1986) Formation of behaviorally effective $17 \beta$-estradiol in the dove brain: steroid control of preoptic aromatase. Endocrinology 118:2180-2187.

Hutchison JB, Wingfield JC, Hutchison RE (1984) Sex differences in plasma concentrations of steroids during the sensitive period for brain differentiation in the zebra finch. J Endocrinol 103:363-369.

Jung-Testas I, Renoir M, Bugnard H, Greene GL, Baulieu E-E (1992) Demonstration of steroid hormone receptors and steroid action in primary cultures of rat glial cells. J Steroid Biochem 41:621-631.

Kitamura K, Newman SL, Campagnoni CW, Verdi JM, Mohandas T, Handley VW, Campagnoni AT (1990) Expression of a novel transcript of the myelin basic protein gene. J Neurochem 54:2032-2041.

Luquin S, Naftolin F, Garcia-Segura LM (1993) Natural fluctuation and gonadal hormone regulation of astrocyte immunoreactivity in dentate gyrus. J Neurobiol 24:913-924.
MacLusky NJ, Naftolin F (1981) Sexual differentiation of the central nervous system. Science 211:1294-1303.

MacLusky NJ, Clark AS, Naftolin F, Goldman-Rakic PS (1987) Estrogen formation in the mammalian brain: possible role of aromatase in sexual differentiation of the hippocampus and neocortex. Steroids 50:461-474.

Mak P, Zenn R, Callard GV (1985) Subcellular distribution and reaction kinetics of aromatase in goldfish brain. Proc 67th Annu Meet Endocrine Soc, p 265.

McEwen BS, Bigeon A, Davis PG, Krey LC, Luine VN, McGinnis MY, Paden CM, Parsons B, Rainbow TC (1983) Steroid hormones: humoral signals which alter brain cell properties and functions. Recent Prog Horm Res 30:41-92.

Naftolin F, Leranth C, Balthazart J (1990) Ultrastructural localization of aromatase immunoreactivity in hypothalamic neurons. Endocr Soc Abstr 192.

Naftolin FK, Ryan KJ, Davies IJ, Reddy VV, Flores F, Petro Z, Kuhn M, White RJ, Takaoka Y, Wolin L (1975) The formation of estrogens by central neuroendocrine tissues. Recent Prog Horm Res 31: 255-319.

Nordeen KW, Nordeen EJ, Arnold AP (1987) Estrogen accumulation in zebra finch song control nuclei: implications for sexual differentiation and adult activation of song behavior. J Neurobiol 18:569582.

Nottebohm F, Amold AP (1976) Sexual dimorphism in vocal control areas of the songbird brain. Science 194:211-213.

Pasmanik M, Schlinger BA, Callard GV (1988) In vivo steroid regulation of aromatase and $5 \alpha$-reductase in goldfish brain and pituitary. Gen Comp Endocrinol 71:175-182.

Pfaff DW (1983) Impact of estrogens on hypothalamic nerve cells: ultrastructural, chemical and electrical effects. Recent Prog Horm Res 39:127-179.

Pfaff DW, Keiner M (1973) Atlas of estradiol concentrating cells in the central nervous system of the female rat. J Comp Neurol 151: 121-158.

Rauscht B, Clapshaw PA, Price J, Noble M, Seifert W (1982) Development of oligodendrocytes and Schwann cells studied with a monoclonal antibody against galactocerebroside. Proc Natl Acad Sci USA 79:2709-2713.

Roselli CE, Resko JA (1986) Effects of gonadectomy and androgen treatment on aromatase activity in fetal monkey brain. Biol Reprod 35:106-1 12.

Roselli CE, Ellenwood WE, Resko JA (1984) Regulation of aromatase activity in rats. Endocrinology 114:192-200.

Sanghera MK, Simpson ER, McPhaul MJ, Kozlowski G, Conley AJ, Lephart ED (1991) Immunocytochemical distribution of aromatase cytochrome $\mathrm{P} 450$ in the rat brain using peptide-generated polyclonal antibodies. Endocrinology 129:2834-2844.

Schlinger BA, Arnold AP (1991) Brain is the major site of estrogen synthesis in a songbird. Proc Natl Acad Sci USA 88:4191-4194.

Schlinger BA, Arnold AP (1992a) Plasma sex steroids and tissue aromatization in hatchling zebra finches: implications for the sexual differentiation of singing behavior. Endocrinology 130:289-299.

Schlinger BA, Arnold AP (1992b) Circulating estrogens in a male songbird originate in the brain. Proc Natl Acad Sci USA 89:76507653 .

Schlinger BA, Arnold AP (1993) Estrogen synthesis in vivo in the adult zebra finch: additional evidence that circulating estrogens can originate in brain. Endocrinology 133:2610-2616.

Schlinger BA, Callard GV (1987) A comparison of aromatase, $5 \alpha$ and $5 \beta$-reductase activities in brain and pituitary of male and female quail (C. c. japonica). J Exp Zool 242:171-180.

Schlinger BA, Callard GV (1989) Localization of aromatase in synaptosomal and microsomal subfractions of quail (Coturnix japonica) brain. Neuroendocrinology 49:434-441.

Schlinger BA, Callard GV (1991) Brain-steroid interactions and the control of aggressiveness in birds. In: Neuroendocrine perspectives, Vol 9 (Muller EE, MacLeod RM, eds), pp 1-43. New York.

Schumacher M, Hutchison RE, Hutchison JB (1991) Inhibition of hypothalamic aromatase activity by 5 beta-dihydrotestosterone. J Neuroendocrinol 3:221-226.

Shea TB, Beerman ML, Fischer I (1993) Transient requirement for vimentin in neuritogenesis: intracellular delivery of anti-vimentin antibodies and antisense oligonucleotides inhibit neurite initiation but not elongation of existing neurites in neuroblastoma. J Neurosci Res 36:66-76. 
Shen P, Campagnoni CW, Kampf K, Schlinger BA, Arnold AP, Campagnoni AT (1994) Isolation and characterization of a zebra finch aromatase cDNA: in situ hybridization reveals high aromatase expression in brain. Mol Brain Res, in press.

Shinoda K, Yagi H, Fujita H, Osawa Y, Shiotani Y (1989a) Screening of aromatase-containing neurons in rat forebrain: an immunohistochemical study with antibody against human placental antigen $\mathrm{X}-\mathrm{P}_{2}$ (hPAX-P ${ }_{2}$ ). J Comp Neurol 290:502-515.

Shinoda K, Sakamoto N, Osawa Y, Pearson J (1989b) Aromatase neurons in the monkey forebrain demonstrated by antibody against human placental antigen X-P $\left(\right.$ hPAX- $\left.\mathrm{P}_{2}\right)$. Soc Neurosci Abstr 15: 232.

Siiteri PK, Febres F (1979) Ovarian hormone synthesis, circulation, and mechanisms of action. In Endocrinology (DeGroot, Cahill, Odell,
Martini, Potts, Nelson, Steinberger, Wingard, eds), pp 1401-1417. New York: Grune and Stratton.

Syapin PJ, Cole R, De Vellis J, Noble EP (1985) Benzodiazepine binding characteristics of embryonic rat brain neurons grown in culture. J Neurochem 45:1797-1801.

Tranque PA, Suarez I, Olmos G, Fernandez B, Garcia-Segura LM (1987) Estradiol-induced redistribution of glial fibrillary acidic protein immunoreactivity in the rat brain. Brain Res 406:348-351.

Vockel A, Pröve E, Balthazart J (1990) Sex- and age-related differences in the activity of testosterone-metabolizing enzymes in microdissected nuclei of the zebra finch brain. Brain Res 511:291-302.

Wade J, Schlinger BA, Hodges L, Arnold AP (1994) Fadrozole: a potent and specific inhibitor of aromatase in the zebra finch brain. Gen Comp Endocr 94:63-61. 